\title{
Cytotoxic Effect of Chitosan-Gold Nanoparticles on Two Cell Lines in Culture
}

\author{
Marius ZĂHAN ${ }^{1}$, Ana-Maria MUŢOIU ${ }^{1}$, Liliana OLENIC ${ }^{2}$, Ileana MICLEA ${ }^{1 *}$, \\ Adriana CRISTE ${ }^{1}$, Vasile MICLEA ${ }^{1}$ \\ ${ }^{1}$ Department of Animal Reproduction, University of Agricultural Sciences and Veterinary Medicine, 3-5, \\ Mănăştur Street, 400372, Cluj-Napoca, Romania. \\ ${ }^{2}$ National Institute for Research and Development of Isotopic and Molecular Technologies, 67-103, \\ Donat Street, 400293, Cluj-Napoca, Romania. \\ *Corresponding author, e-mail: ileana.miclea@usamvcluj.ro
}

Bulletin UASVM Animal Science and Biotechnologies 74(2)/ 2017

Print ISSN 1843-5262; Electronic ISSN 1843-536X

DOI:10.15835/buasvmcn-asb: 0017

\begin{abstract}
Among metallic nanoparticles gold possess several unique properties. It has been argued that AuNPs have significant toxicity both in vitro and in vivo but that coating may partially prevent harmful effects. Chitosan is a natural polysaccharide derivative of chitin known to have immunoenhancing effects, antitumor, antifungal and antimicrobial activities. The aim of this study was to investigate the cytotoxic effect of chitosan-AuNPs on C26 (murine colon carcinoma) and HeLa (human cervix carcinoma) cell lines. C26 and HeLa cells were exposed to 10 and $60 \mathrm{~nm}$ sized chitosan-AuNPs at five different concentrations (5, 10, 25, 50 and $100 \mu \mathrm{g} / \mathrm{ml})$. After $24 \mathrm{~h}$ of incubation, cytotoxicity was assessed by the MTT colorimetric method and IC50 values were calculated. In C26 cells $60 \mathrm{~nm}$ particles were more toxic than $10 \mathrm{~nm}$ particles. On the other hand in HeLa cells the situation was reversed and $10 \mathrm{~nm}$ particles had the most harmful effect at a concentration 2.5 times smaller than that of $60 \mathrm{~nm}$ particles. Our results could suggest that chitosan-AuNPs have an antiproliferative effect on C26 and HeLa cell lines but that this depends on cell type and is influenced by particle size and concentration.
\end{abstract}

Keywords: C26, chitosan-Au NPs, HeLa, antiproliferative

\section{INTRODUCTION}

According to a recently suggested definition of the European Union nanotechnologies involve particles shorter than $100 \mathrm{~nm}$ at least in one dimension (BSI-PAS71, 2005). They are called 'intended' particles because they are intentionally produced in order to fulfil specific functions or gain characteristics in science, technology, medicine, industries and many other applications (Kreyling et al., 2006; Pop et al., 2015).

Because of its chemical inertness, gold has been used internally in humans for the past 50 years, from teeth to implants to radioactive gold used in cancer treatment (Mfhlen and Beller, 1979; Rosenberg et al., 1985).

The fact that amine (Selvakannan et al., 2003) and thiol (Templeton et al., 2000) groups bind strongly to AuNPs has enabled their surface modification with amino acids (Selvakannan et al., 2004; Joshi et al., 2004), proteins (Phadtare et al., 2003) and DNA (Rosi et al., 2006). This has lead to important biomedical applications (reviwed by Shukla et al., 2005). Nanotechnology has broad applications in fighting cancer and can be employed in molecular imaging, molecular diagnosis, targeted therapy and bioinformatics (Cai et al., 2008).

If clinical applications for NPs are to be developed their biocompatibility is crucial (Shukla et al., 2005) and further studies of their toxicity are required. It has been argued that naked AuNPs have significant toxicity both in vitro and in vivo, while appropriate coating with chitosan 
or PEG may partially prevent their harmful effects (Jokerstet al., 2011; Sabella et al., 2011).

Chitosan is a natural polysaccharide derivative of chitin with biodegradable, biocompatible, non-toxic characteristics (Qi et al., 2005) and it is known to have immunoenhancing effects, antitumor, antifungal and antimicrobial activities (Roller and Covill, 1999; Wang et al., 2011; Zheng et al., 2003). Beside these, it can act as a stabilizing agent and can be used to tailor nanocomposite properties and also to provide long-term stability to the nanoparticles by preventing particle agglomeration (Chen et al., 2013). Bhumkar et al. (2007) developed a new strategy to exploit the use of chitosan as a reducing agent for the production of AuNPs. Interestingly, chitosan-AuNPs were bactericidal against antibiotic resistant strains of Staphylococcus aureus and Pseudomonas aeruginosa (Regiel-Futyra et al., 2015).

In vivo and in vitro studies regarding cytotoxicity of nanoparticles have contradictory results and there is still not enough information on their effects. In this context, we investigated the cytotoxic effect of chitosan-AuNPs on C26 (murine colon carcinoma) and HeLa (human cervical carcinoma) cell lines.

\section{MATERIALS AND METHODS}

Characterization of chitosan gold nanoparticles

Two solutions of chitosan-gold nanoparticles (chitosan-AuNPs) were graciously provided by the National Institute for Research and Development of Isotopic and Molecular Technologies ClujNapoca. Nanoparticles were characterized by absorbance reading at $300-800 \mathrm{~nm}$ using a V-630 UV-Vis Spectrophotometer in order to assess their size.

Cell lines and cell culture

Murine colon carcinoma cell line C26 (Cell Lines Service $\mathrm{GmbH}$, Eppelheim, Germany) was maintained in RPMI-1640 medium without antibiotics but supplemented with $1 \mathrm{mM}$ glutamine and $10 \%$ foetal bovine serum while for human tumour cervical HeLa (ATCC CCL-2) MEM medium supplemented with the same reagents was used.

MTT cell proliferation assay

Cytotoxicity was assessed using the 3-(4,5-dimethylthiazol-2-yl)-2,5-diphenyltetra- zolium bromide (MTT) colorimetric method. C26 and HeLa cells were seeded at a concentration of $1 \cdot 10^{6} / \mathrm{ml}$ into 96-well microplates and kept in their respective media for 24 hours. Afterwards, cells were exposed for 24 hours to media containing characterised chitosan-AuNPs from the two solutions at five different concentrations: 5, 10, 25, 50 and $100 \mu \mathrm{g} / \mathrm{ml}$ using 5 wells for each concentration. Chitosan-Au NPs had been sterilized by filtration through $0.22 \mu \mathrm{m}$ pores. The media containing chitosan-AuNPs was eliminated and cells were washed with $150 \mu$ phosphate buffered saline (PBS) which was then replaced with $150 \mu \mathrm{l}$ MTT solution in PBS $(0.5 \mathrm{mg} / \mathrm{ml})$. The resulting formazan particles were solubilized with $200 \mu \mathrm{l}$ dimethyl sulfoxide. The absorbance was read with the HT Synergy microplate plate reader (BioTek Instruments, USA) at $550 \mathrm{~nm}$ and expressed relative to the background absorbance read at $630 \mathrm{~nm}$. Experiments were repeated 3 times. Results were expressed as percentages of antiproliferative activity with respect to an untreated control and based on them IC50 values were calculated using the Excel program (Microsoft Corporation, USA).

\section{RESULTS AND DISCUSSIONS}

Characterization of chitosan-AuNPs

Absorbance measurements indicated that particle diameter was $10 \mathrm{~nm}$ for the first solution while the second contained $60 \mathrm{~nm}$ sized particles.

Cell proliferation

We found that chitosan-AuNPs decreased cell proliferation in a dose dependent manner (Fig. 1). As shown by the IC50 values in C26 cells the antiproliferative effect was higher for $60 \mathrm{~nm}$ nanoparticles $(25.70 \mu \mathrm{g} / \mathrm{ml})$ than for $10 \mathrm{~nm}$ nanoparticles $(36.70 \mu \mathrm{g} / \mathrm{ml})$.

The antiproliferative effect was higher in C26 cells than in HeLa cells for both types of chitosan-AuNPs. For HeLa cells the situation was different, with the $10 \mathrm{~nm}$ nanoparticles having a more powerful antiproliferative activity (IC50: $43.36 \mu \mathrm{g} / \mathrm{ml}$ ) than the $60 \mathrm{~nm}$ nanoparticles (IC50: $107.43 \mu \mathrm{g} / \mathrm{ml}$ ).

Cell morphology was visibly altered in both lines (Fig. 2). Characteristic changes such as vacuolation, cytoplasmic granulations and cell detachment were apparent after a 24 hour exposure and became worse as concentration increased. 

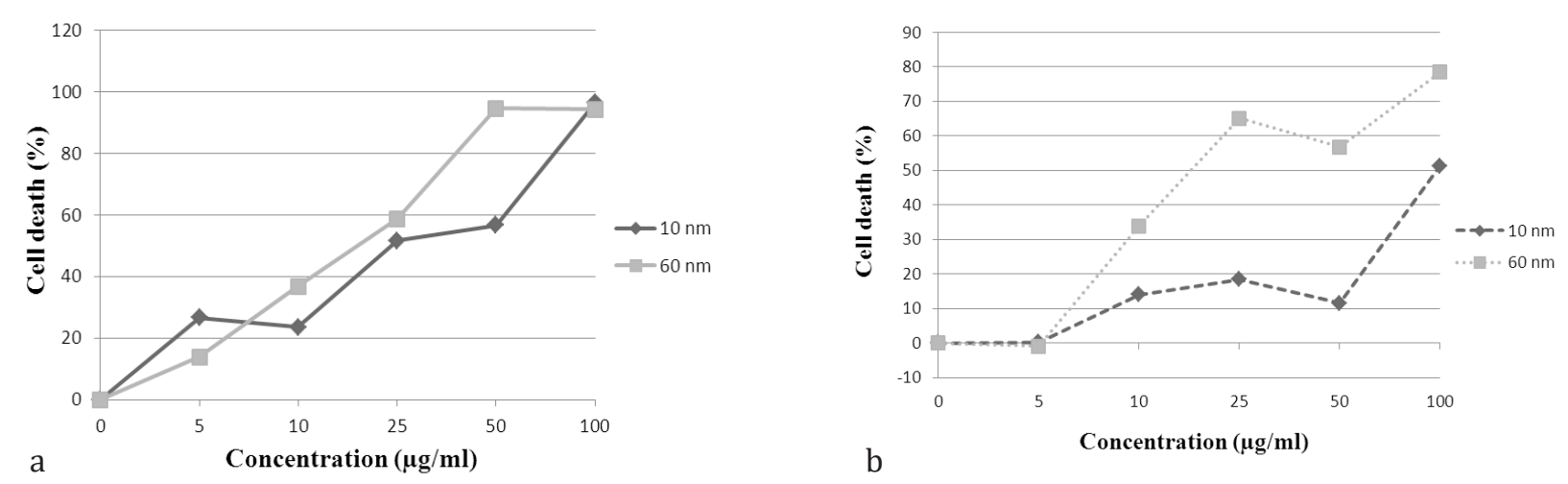

Fig. 1. Antiproliferative effect of chitosan-AuNPs in C26 cells (a) and HeLa cells (b)

In vivo, Au-NPs sized 10-15 $\mathrm{nm}$ have been localised in all tissues including blood, liver, lung, spleen, kidney and heart of mice while particles between 200-250 nm showed very minute presence in organs including blood, brain and spleen (reviewed by Fratoddi et al, 2014). Stefan et al. (2013) have demonstrated that smaller sized chitosan-AuNPs $(12 \mathrm{~nm})$ show protective effects against toxicity induced by lipopolysaccharides in Wistar rats.
In vitro, cytotoxicity of AuNPs has been studied on various cell lines such as human skin fibroblasts (HeLa), human leukemia (K562), human hepatocarcinoma (HepG2), human breast carcinoma (SK-BR-3) (Fratoddi et al, 2014).

Chitosan-AuNPs have been shown to induce cytotoxic effects on neural and non-neural cell types (Gao et al., 2012) but also to inhibit proliferation of human gastric carcinoma cell line MGC803 (Qi et al., 2005) while Choi et al. (2015)
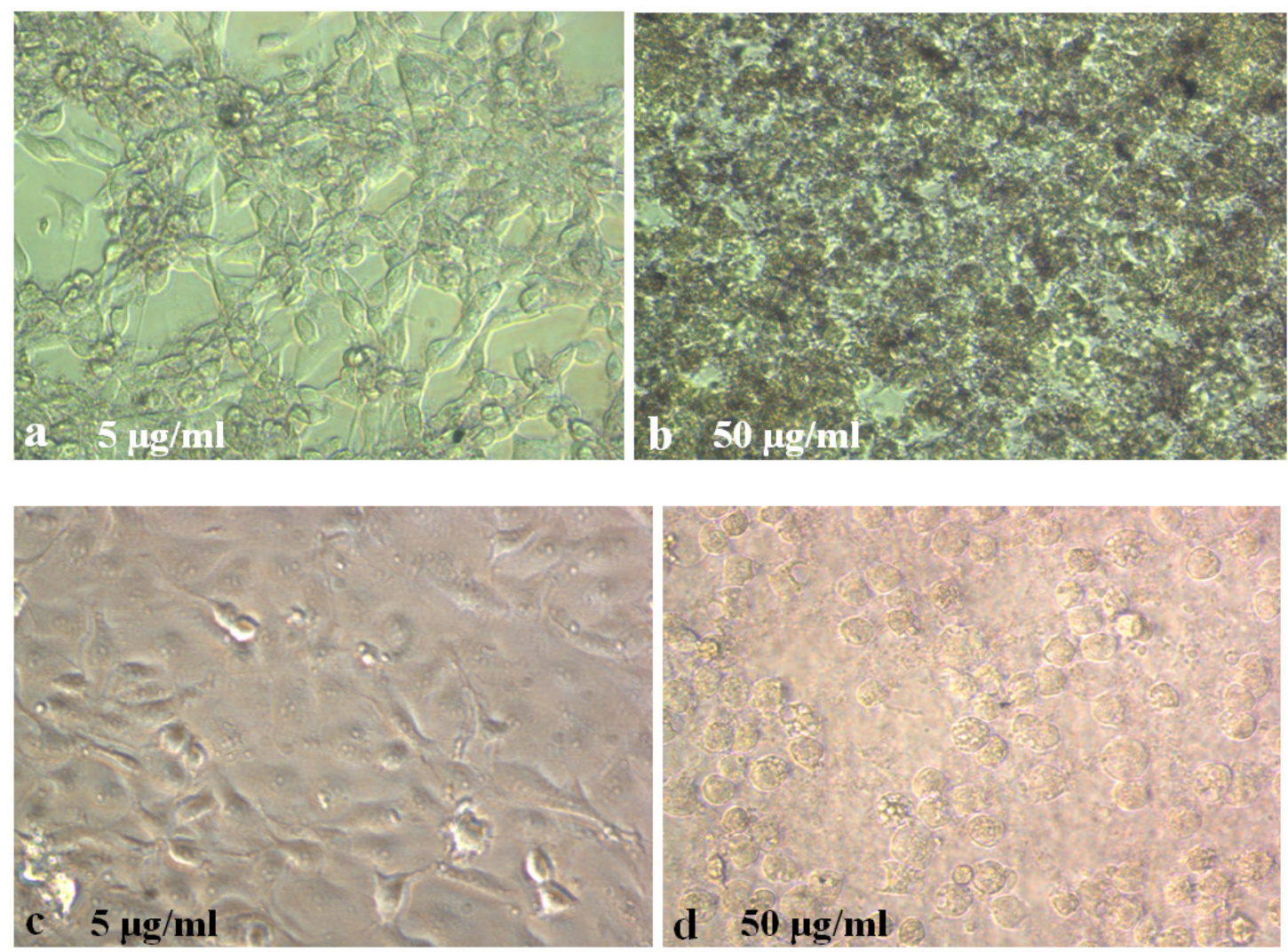

Fig. 2. Morphology of C26 cells treated with $60 \mathrm{~nm}$ chitosan-AuNPs (a, b) and HeLa cells treated with $10 \mathrm{~nm}$ chitosan-AuNPs (c,d). 
found that these appeared to provoke cell death in human lung carcinoma cells, line THP.

In the cell Au-NPs have been found free in the cytoplasm but also encased in a membranebound vacuole, possibly an endosome or lysosome by Murdock (2010) and inside lysosomes and the reticuloendothelial network by Shukla et al. (2005).

Mironava et al. (2010) found that differently sized AuNPs: $45 \mathrm{~nm}$ at a concentration of $20 \mu \mathrm{g} /$ $\mathrm{ml}$ and $13 \mathrm{~nm}$ at $142 \mu \mathrm{g} / \mathrm{ml}$ were sequestered inside large vacuoles without showing nuclei penetration. On the other hand Pan et al. (2007) reported that 1 and $4 \mathrm{~nm}$ gold nanoparticles were the most cytotoxic toward connective tissue mouse fibroblasts (L929 mouse), cervical carcinoma epithelial cells (HeLa), mouse macrophages (J774A1) and melanoma cells (SK-Mel-28) (IC50 approximately 30-46 $\mu \mathrm{g} / \mathrm{ml}$ ), whereas $15 \mathrm{~nm}$ AuNPs were not toxic at concentrations up to 100 -fold higher (up to $6300 \mu \mathrm{g} / \mathrm{ml}$ ). Conversely, Hondroulis et al. (2010) observed no difference in cytotoxicity of 10 and $100 \mathrm{~nm}$ AuNPs and Connor et al. (2005) found no cytotoxic effects for $18 \mathrm{~nm}$ AuNPs up to a $100 \mu \mathrm{M}$ concentration. AuNPs have been reported as being nontoxic and biocomapatible with mouse macrophages (RAW264.7 cell line) (Shukla et al., 2005). In contrast, $10 \mathrm{~nm}$ AuNPs coated with chitosan were found to be cytotoxic to human acute monocytic leukemia line THP-1 (Boyles et al., 2015). Chitosan coated AuNPs have been shown to promote bone formation (Choi et al., 2015) and proposed as carriers for insulin delivery (Bhumkar et al., 2007). Our research shows that chitosan-AuNPs have an antiproliferative effect on C26 and HeLa cell lines. In murine colon carcinoma (C26) cells larger particles $(60 \mathrm{~nm})$ were more toxic than smaller ones (10 nm). On the other hand in human cervical carcinoma (HeLa) cells the situation was reversed and $10 \mathrm{~nm}$ particles did the most had the most detrimental effect at a concentration 2.5 times smaller than that of $60 \mathrm{~nm}$ particles.

\section{CONCLUSION}

Given the contradictory nature of results in the gold nanoparticle field and the recent use of chitosan-gold nanocomposites our aim was to investigate their cytotoxicity in murine colon carcinoma and human cervical carcinoma cells. Results of this research could suggest that the antiproliferative effect of chitosan-AuNPs depends on cell type and is influenced by particle size and concentration.

\section{REFERENCES}

1. Bhumkar DR, Joshi HM, Sastry M, Pokharkar V (2007). Chitosan reduced gold nanoparticles as novel carriers for transmucosal delivery of insulin. Pharm Res 24(8):14151426.

2. Bielinska A, Eichman JD, Lee I, Baker JR Jr, Balogh LJ (2002). Imaging \{Au0-PAMAM $\}$ gold-dendrimer nanocomposites in cells. Nanopart Res 4:395-403.

3. Boyles MS, Kristl T, Andosch A, Zimmermann M, Tran N, Casals E, Himly M, Puntes V, Huber CG, Lütz-Meindl U, Duschl A (2015). Chitosan functionalisation of gold nanoparticles encourages particle uptake and induces cytotoxicity and pro-inflammatory conditions in phagocytic cells, as well as enhancing particle interactions with serum components. J Nanobiotechnology 13:84.

4. BSI-PAS71 (2005). Vocabulary - Nanoparticles. British Standard Institution (BSI). http://www.bsi-global.com/ nano.

5. Cai W, Gao T, Hong H, Sun J (2008). Applications of gold nanoparticles in cancer nanotechnology. Nanotechnol Sci Appl 1: 17-32.

6. Chen Z, Wang Z, Xu H, Liu J (2013). Chitosan-capped gold particles for selective and colorimetric sensing of heparin. J Nanopart Res 15:1-9.

7. Choi SY, Song MS, Ryu PD, Lam AT, Joo SW, Lee SY (2015). Gold nanoparticles promote osteogenic differentiation in human adipose-derived mesenchymal stem cells through the Wnt/ $\beta$-catenin signaling pathway. Int J Nanomedicine 10:4383-4392.

8. Choi SY, Jang SH, Park J, Jeong S, Park JH, Ock KS., Kangtaek Lee K, Yang SI, Joo S-W, Ryu PD, Lee SY (2012). Cellular uptake and cytotoxicity of positively charged chitosan gold nanoparticles in human lung adenocarcinoma cells. J Nanopart Res 14(12):1234.

9. Connor EE, Mwamuka J, Gole A, Murphy CJ, Wyatt MD (2005). Gold nanoparticles are taken up by human cells but do not cause acute cytotoxicity. Small 1:325-327.

10. Fratoddi I, Venditti I, Cametti C, Russo MV (2015). How toxic are gold nanoparticles? The state-of-the-art. Nano Res 8(6):1771-1799.

11. Gao W, Lai JC, Leung SW (2012). Functional enhancement of chitosan and nanoparticles in cell culture, tissue engineering, and pharmaceutical applications. Front Physiol 3:321.

12. Hondroulis E, Liu C, Li C-Z (2010). Whole cell based electrical impedance sensing approach for a rapid nanotoxicity assay. Nanotechnology 21:315103.

13. Jokerst JV, Lobovkina T, Zare RN, Gambhir SS (2011). Nanoparticle PEGylation for imaging and therapy. Nanomedicine 6:715-728.

14. Joshi H, Shirude PS, Bansal V, Ganesh KN, Sastry M (2004). Isothermal titration calorimetry studies on the biding of amino acids to gold nanoparticles. J Phys Chem B 108:11535-11540. 
15. Kreyling WG, Semmler-Behnke M, Möller W (2006). Health implications of nanoparticles. J Nanopart Res 8(5):543-562.

16. Mfhlen KH, Beller FK (1979). Use of radioactive gold in the treatment of pleural effusions caused by metastatic cancer. J Cancer Res Clin Oncol 94:81-5.

17. Mironova T, Hadjiargyrou $M$, Simon M, Jurkovski V, Railovich MH (2010). Gold nanoparticles cellular toxicity and recovery: effect of size, concentration and exposure time. Nanotoxicology 4:120-137.

18. Murdock RC (2010). Radio frequency controlled stimulation of intracellular gold or silver nanoparticle conjugates for use as potential sensors or modulators for biological function methods. Master Thesis, Wright State University, Ohio.

19. Pan Y, Neuss S, Leifert A, Fischler M, Wen F, Simon U, Schmid G, Brandau W, Jahnen-Dechent W (2007). Sizedependent cytotoxicity of gold nanoparticles. Small 3:1941-1949.

20. Phadtare S, Kumar A, Vinod VP, Dash CV, Rao M, Shukla PG, Sivaram S, Sastry M (2003). Direct assembly of gold nanoparticle "shells" on polyurethane microsphere "cores" and their application as enzyme immobilization templates. Chem Mater 15(10):1944-1949.

21. Pop OL, Diaconeasa Z, Mesaroș A, Vodnar DC, Cuibus L, Ciontea L, Socaciu C (2015). FT-IR studies of cerium oxide nanoparticles and natural zeolite materials. Bulletin UASVM Food Science and Technology 72(1):50-55.

22. Qi L-F, Xu Z-R, Li Y, Jiang X, Han X-Y (2005). In vitro effects of chitosan nanoparticles on proliferation of human gastric carcinoma cell line MGC803 cells. World J Gastroenterol 11(33):5136-5141.

23. Regiel-Futyra A, Kus-Liśkiewicz M, Sebastian V, Irusta S, Arruebo M, Stochel G, Kyzioł A (2015). Development of noncytotoxic chitosan-gold nanocomposites as efficient antibacterial materials. ACS Appl Mater Interfaces 7(2):1087-1099.

24. Roller S, Covill N (1999). The antifungal properties of chitosan in laboratory media and apple juice. Int J Food Microbiol 47:67-77.
25. Rosenberg SJ, Loening SA, Hawtrey CE, Narayana AS, Culp DA (1985). Radical prostatectomy with adjuvant radioactive gold for prostatic cancer: a preliminary report. J Urol 133:225-227.

26. Rosi NL, Giljohann DA, Thaxton CS, Lytton-Jean AKR, Han MS, Mirkin CA (2006). Oligonucleotide-modified gold nanoparticles for intracellular gene regulation. Science 312:1027-1030.

27. Sabella S, Galeone A, Vecchio G, Cingolani R, Pompa PP (2011). AuNPs are toxic in vitro and in vivo: a review. J Nanosci Lett 1:145-165.

28. Selvakannan P R, Mandal S, Phadtare S, Pasricha R, Sastry M (2003). Capping of gold nanoparticles by the amino acid lysine renders them water-dispersible. Langmuir 19 (8):3545-3549.

29. Selvakannan P, Mandal S, Phadtare S, Gole A, Pasricha R, Adyanthaya SD, Sastry M (2004). Water-dispersible tryptophan-protected gold nanoparticles prepared by the spontaneous reduction of aqueous chloroaurate ions by the amino acid. J Colloid Interface Sci 269(1):97-102.

30. Shukla R, Bansal V, Chaudhary M, Basu A, Bhonde RR, Sastry M (2005). Biocompatibility of gold nanoparticles and their endocytotic fate inside the cellular compartment: a microscopic overview. Langmuir 21(23):10644-10654.

31. Stefan M, Melnig V, Pricop D, Neagu A, Mihasan M, Tartu L (2013). Attenuated effects of chitosan-capped gold nanoparticles on LPS-induced toxicity in laboratory rats. Mat Sci Engineering C 33:550-556.

32. Templeton AC, Wuelfing WP, Murray RW (2000). Monolayer-protected cluster molecules. Acc Chem Res 33(1):27-36.

33. Wang JJ, Zeng ZW, Xiao RZ, Xie T, Zhou GL, Zhan XR, Wang SL (2011). Recent advances of chitosan nanoparticles as drug carriers. Int J Nanomedicine 6:765-74.

34. Zheng LY, Zhu JF (2003). Study on antimicrobial activity of chitosan with different molecular weights. Carbohyd Polym 54:527-530. 